\title{
Nutritional Chemical Analysis of Taro Colocasia esculenta Schott) Accessions from the State of Tabasco, Mexico
}

\author{
Sánchez-Chino, Xaris M. ${ }^{1}$; Corzo-Ríos, Luis J. ${ }^{2}$; Jiménez-Martínez, Cristian ${ }^{3}$; \\ Argüello-García, Elizabeth ${ }^{4}$; Martínez-Herrera, Jorge ${ }^{5^{*}}$ \\ 1 Cátedra-CONACyT, Departamento de Salud, El Colegio de la Frontera Sur, Carretera Villahermosa- \\ Reforma km 15.5, Ranchería Guineo, sección II, Villahermosa, Tabasco. C.P. 86280. \\ 2 Unidad Profesional Interdisciplinaria de Biotecnología, Instituto Politécnico Nacional, Av. Acueducto s/n, \\ Col. La Laguna Ticomán, Giudad de México, México, G.P. 07340. \\ 3 Escuela Nacional de Ciencias Biológicas, Instituto Politécnico Nacional, Av. Wilfrido Massieu. Esq. Manuel \\ Stampa, Gustavo A. Madero, Ciudad de México, México, C.P. 11340. \\ 4 Universidad Popular de la Chontalpa, Carretera Cárdenas-Huimanguillo Km 2 s/n, Ranchería, Paso y \\ Playa, Heroica Cárdenas, Tabasco, México, G.P. 86597. \\ 5 Instituto Nacional de Investigaciones Forestales, Agrícolas y Pecuarias, Campo Experimental Huimanguillo, \\ Km. 1. Carretera Huimanguillo-Cárdenas, Tabasco, México. G.P. 86400. \\ * Correspondence: martinez.jorge@inifap.gob.mx
}

Gitation: Sánchez-Chino, X. M., Corzo-Ríos, L. J., Jiménez-Martínez, C., Argüello-García, E., \& MartínezHerrera, J. (2021). Nutritional Chemical Analysis of Taro (Colocasia esculenta Schott) Accessions from the State of Tabasco, Mexico. Agro Productividad. https://doi.org/10.32854 agrop.vl4i10.2074

Editor in Chief: Dr. Jorge Cadena Iñiguez

Received: July 23, 2021.

Accepted: October 13, 2021.

Published on-line: November 8, 2021

This work is licensed under a Creative Commons Attribution-NonCommercial 4.0 International license.

\section{ABSTRACT}

Objective: To determine the main nutritional properties and content of bioactive compounds of five varieties of taro, grown in the municipalities of Huimanguillo and Cunduacán, Tabasco.

Methodology: The Campechana, Chiapaneca, Tabasqueña, Dulce (P1 and P2) varieties were evaluated to determine their proximal chemical composition, non-nutritional compounds, and antioxidant activity. An analysis of variance and the Tukey test were applied to the data obtained.

Results: These varieties had a protein, lipid, ash, and moisture content of 1.13-3.95, 0.64-2.94, 1.58-7.32, and $2.28-5.34 \%$, respectively. In all cases, the starch content stood out with $62.7-74.7 \%$ values. This compound is important in the food industry because its functional properties enable its use in various food systems or other applications. Among the non-nutritional compounds, the following concentrations were identified: phytates (0.235-0.40 Eq/g sodium phytate/100 g sample); total phenols (0.54-5.76 Eq/g gallic acid/100 g sample); condensed phenols (1.20-1.51 Eq/mg catechin/100 g sample); saponins (0.37-1.02 Eq/mg Diosgenin/100 g sample); and trypsin inhibitors (0.00-0.70 UIT/100 g sample). Finally, the antioxidant activity had 0.29-0.57 $\mathrm{Eq} / \mathrm{mg}$ of trolox/g of flour values.

Limitations: This work had no limitations.

Conclusions: The varieties evaluated presented low concentration of non-nutritional compounds and adequate antioxidant activity; therefore, the taro varieties from the State of Tabasco can be considered sources of starch and compounds with antioxidant activity.

Keywords: Colocasia esculenta, antioxidants, taro, nutritional, starch.

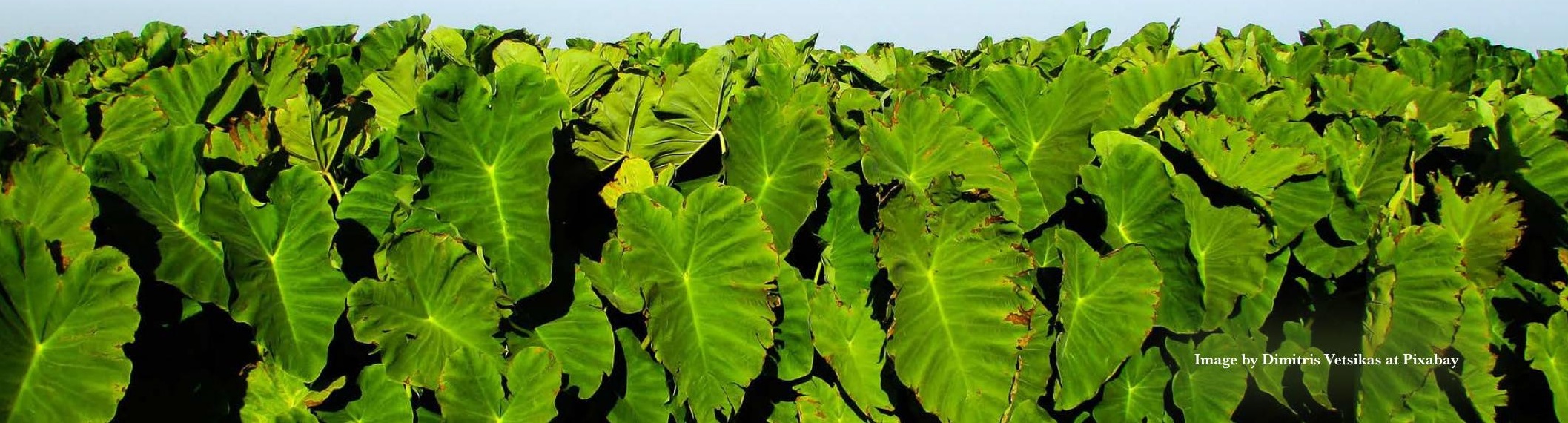




\section{INTRODUCTION}

Taro (Colocasia esculenta Schott) is an annual herbaceous with a perennial life cycle (Araceae); it is native to Asia, Africa, and Oceania. It has round ovoid tubers, starchy flesh, and dark brown skin (Viloria and Córdova, 2008), it is both used as food for humans and animals, although it also has industrial uses (Madrigal et al., 2018; Temesgen, 2015). The value of taro as a food is attributed to the easy digestibility of its starch granules, its high energy value, and its content of vitamins $\mathrm{A}$ and $\mathrm{C}$, as well as of some elements of the B complex and minerals, such as calcium, phosphorus, and iron (Onwueme, 1999; Temesgen, 2015). Before they are consumed, they must be baked, roasted or fried; its new leaves and petioles can be consumed as vegetables in traditional meat and fish dishes (Lamrot, 2018; Púa et al., 2019).

In Mexico taro is grown in Puebla, Sinaloa, and Oaxaca; however, it has only prospered as a commercial product in Veracruz. The cultivation of taro has increased in the State of Tabasco. Some producers in the municipalities of Cunduacán and Huimanguillo, Tabasco, have used some hectares to grow taro, but they are still not enough. Considering the agroclimatic conditions, the agronomic management is inadequate. Therefore, producers should become acquainted with the nutritional potential of this species, especially its bromatological characteristics and its functionality, in order to increase the value chain that will support greater commercialization and consumption in Tabasco.

Some producers have begun to use taro to make breadmaking flour mixed with wheat flour or to prepare a traditional drink known as horchata; as a result of this situation, the objective of this study was to determine the proximal chemical composition of nonnutritional compounds and the antioxidant activity of the following taro varieties: Campechana (white), Chiapaneca (purple), Tabasqueña (Coco) and Dulce (P1 and P2). The cultivation took place in in the Cumuapa 2nd settlement of the municipality of Cunduacán, and the Ejido José Santamaría and Tierra Nueva 3rd Section settlements of the municipality of Huimanguillo in the State of Tabasco.

\section{MATERIALS AND METHODS}

\section{Sampling Sites}

The sampling sites were: R/A Cumuapa 2nd section, Cunduacán, Tabasco, México $\left(18^{\circ}\right.$ 0.1' 1.23" N, 93 10' 11.2" W); R/A Ejido Francisco Santamaría Chontalpa Huimanguillo $\left(17^{\circ} 63^{\prime} 43^{\prime}\right.$ N, 93 49' 60" W); R/A Tierra Nueva 3rd section, Huimanguillo, Tabasco $\left(17^{\circ} 73^{\prime} 025^{\prime}\right.$ N, $\left.93^{\circ} 46^{\prime} 23^{\prime \prime} \mathrm{W}\right)$. The samples were analyzed in the Laboratorio de Suelos, Plantas y Agua del INIFAP-Campo Experimental Huimanguillo (Instituto Nacional de Investigaciones Forestales, Agrícolas y Pecuarias).

\section{Sample Preparation}

Two corms from each of the five accessions of taro - Campechana, Chiapaneca (purple), Tabasqueña, and Dulce (P1 and P2) - were washed with distilled water; the corms were peeled, and they were cut into $0.5 \mathrm{~cm}$ thick slices; subsequently the slices were dried at $75^{\circ} \mathrm{C}$ for $24 \mathrm{~h}$; finally, they were ground using a commercial blender to 
obtain flour (60 mesh) which was stored in hermetic bags. The percentage of dry matter and its moisture content was calculated using the following equation:

$$
\% \text { materia seca }=\frac{P i(\text { peso después de la desecación })}{p(\text { peso antes de la desecación })} \times 100
$$

\section{Proximal Chemical Analysis}

Its bromatological composition was determined according to the following AOAC methods (2005): humidity (934.01), ash (942.05), proteins [976.05, using as conversion factor (N×6.25)], and lipids (2003.06). The Fehling method - established in the NMX-F-277-1991 standard - was used to quantify the total starch.

\section{Non-Nutritional Compounds}

The trypsin inhibitors activity was determined according to Liu and Markakis (1989) and it was reported as UIT/100 $\mathrm{g}$ of sample. Phytic acid content was determined using the colorimetric procedure described by Vaintraub and Lapteva (1988). The results were expressed as Eq/g sodium phytate/100 g sample, using phytic acid as standard (phytic acid sodium salt hydrate, P8810; Sigma, St. Louis, MO, USA).

Saponins were quantified using the spectrophotometric method described by Hiai et al. (1976). The concentration of saponins was read from a standard curve of different concentrations of diosgenin (D1634, Sigma, St. Louis, MO, USA) in 80\% aqueous methanol and expressed as the equivalent of diosgenin. Finally, the content of total phenolic compounds was determined using the Folin-Ciocalteu method (Singleton et al., 1999), with gallic acid as standard for the calibration curve. The results were reported as Eq/mg of gallic acid/100 g of sample.

\section{Antioxidant Activity}

The antioxidant activity was determined based on the $\mathrm{ABTS}^{+}$radical according to the findings of Kuskoski et al. (2004) and it was carried out using the ethanolic extracts of taro flour (1:10 flour: ethanol, ambient T, $16 \mathrm{~h}$ ). The absorbance values were obtained from a trolox curve (6-hydroxy-2,5,7,8-tetramethylchroman-2-carboxylic acid) and the results were reported as $\mathrm{Eq} / \mathrm{mg}$ of trolox/g of flour.

\section{Statistical Analysis}

The Statistical Analysis System (SAS) software V.6.12, USA, was used to carry out an analysis of variance (ANOVA) and the Tukey test in order to analyze the data obtained. All parameters were tested for significance $(\mathrm{P} \leq 0.05)$.

\section{RESULTS AND DISGUSSION}

\section{Proximal Chemical Analysis}

According to Table 1, the Chiapaneca accession presented the highest moisture content (84.7\%), while the Dulce P1 and P2 samples showed the lowest moisture values (62.7 and 
Table 1. Dry Matter and Moisture in Five Taro Accessions.

\begin{tabular}{l|c|c}
\multicolumn{1}{c|}{ Accessions } & Dry matter (\%) & Moisture (\%) \\
\hline Campechana & $25.06^{\mathrm{b}}$ & $74.9^{\mathrm{b}}$ \\
\hline Chiapaneca & $15.3^{\mathrm{c}}$ & $84.7^{\mathrm{c}}$ \\
\hline Tabasqueña & $28.62^{\mathrm{b}}$ & $71.3^{\mathrm{b}}$ \\
\hline Dulce P1 & $37.3^{\mathrm{a}}$ & $62.7^{\mathrm{a}}$ \\
\hline Dulce P2 & $37.0^{\mathrm{a}}$ & $63.0^{\mathrm{a}}$ \\
\hline
\end{tabular}

* Means with the same letters in each column are statistically equal (Tukey, P $\leq 0.05)$.

$63.0 \%$, respectively). In order to obtain a higher taro flour yield, taro must have a higher dry matter content: the Dulce P1 and P2 samples, followed by the Tabasqueña sample showed the highest dry matter content. Ferreira et al. (1990) reported similar values to those found in this work: $80 \%$ humidity. This is a typical characteristic of tubers.

On the one hand, starch is the main component of taro (Table 2) and it represents $62-74 \%$ of its dry weight; these values are close to the $65-80 \%$ starch content reported by Madrigal et al. (2018). On the other hand, Rodríguez-Miranda et al. (2011) reported approximately $88 \%$ starch content, highlighting that taro starch has good water solubility capacity and good water and oil absorption, and that it also functions as an emulsifier; therefore, it could be used as raw material in the food industry.

The protein content of the taro samples ranged from 1.13 to $3.95 \mathrm{~g} / 100 \mathrm{~g}$; these results match those reported by Torres et al. (2013) and Antonio et al. (2009) who found a protein content of 2.08 and $1.35 \mathrm{~g} / 100 \mathrm{~g}$. These values are relatively low; therefore, using taro as a source of starch would provide a purer carbohydrate.

The lipid concentration ranged from 0.64 to $2.94 \mathrm{~g} / 100 \mathrm{~g}$. These values were similar to the findings of Madrigal et al. (2018) (1 and $1.26 \mathrm{~g} / 100 \mathrm{~g}$ ) and Rodríguez-Miranda $e t$ al. (2011) (0.79 g/100 g). The lipid concentration was higher than $2 \mathrm{~g} / 100 \mathrm{~g}$ in the Dulce (P1 and P2) and the Campechana varieties; therefore, studying the shelf life of these flours would an important topic for future research.

Regarding the ash content, the results ranged from 1.91 to $7.32 \mathrm{~g} / 100 \mathrm{~g}$. Púa et al. (2019) and Madrigal et al. (2018) reported similar results: 7.65 and $3.23 \mathrm{~g} / 100 \mathrm{~g}$, respectively. Potassium has been reported as one of the minerals with the highest concentration; it is an important element in plant metabolism, since it is essential for the biosynthesis of

Table 2. Chemical Composition of the Different Taro Accessions (g/100 of sample B. S).

\begin{tabular}{c|c|c|c|c|c}
\hline Accession & Protein & Lipids & Ash & Moisture & Starch \\
\hline Campechana & $1.13 \pm 0.02^{\mathrm{e}}$ & $2.11 \pm 0.02^{\mathrm{c}}$ & $2.47 \pm 0.11^{\mathrm{c}}$ & $5.11 \pm 0.05^{\mathrm{b}}$ & $74.7 \pm 0.01^{\mathrm{a}}$ \\
\hline Chiapaneca & $2.36 \pm 0.01^{\mathrm{b}}$ & $0.64 \pm 0.01^{\mathrm{e}}$ & $7.32 \pm 0.06^{\mathrm{a}}$ & $2.28 \pm 0.02^{\mathrm{e}}$ & $62.7 \pm 0.02^{\mathrm{e}}$ \\
\hline Tabasqueña & $3.95 \pm 0.18^{\mathrm{a}}$ & $1.42 \pm 0.03^{\mathrm{d}}$ & $4.13 \pm 0.13^{\mathrm{b}}$ & $5.34 \pm 0.00^{\mathrm{a}}$ & $72.0 \pm 0.01^{\mathrm{b}}$ \\
\hline Dulce P1 & $1.42 \pm 0.02^{\mathrm{d}}$ & $2.94 \pm 0.03^{\mathrm{a}}$ & $1.58 \pm 0.05^{\mathrm{e}}$ & $3.35 \pm 0.01^{\mathrm{c}}$ & $70.1 \pm 0.22^{\mathrm{c}}$ \\
\hline Dulce P2 & $1.71 \pm 0.01^{\mathrm{c}}$ & $2.61 \pm 0.12^{\mathrm{b}}$ & $1.91 \pm 0.01^{\mathrm{d}}$ & $3.35 \pm 0.01^{\mathrm{d}}$ & $68.4 \pm 0.01^{\mathrm{d}}$ \\
\hline
\end{tabular}

* Means with the same letters in each column are statistically equal (Tukey, $\mathrm{P} \leq 0.05$ ). 
carbohydrates (Madrigal et al., 2018). Minerals are important for human nutrition, as well as for the vegetable itself, and their concentration is usually higher in the peel than in the flesh (Subramanian et al., 2011).

\section{Non-Nutritional Compounds}

The presence of non-nutritional compounds can interfere with the assimilation or digestibility of proteins or carbohydrates. In this regard, the non-nutritional compounds of taro accessions were analyzed. Table 3 shows a significant variation in the activity of trypsin inhibitors ( $\mathrm{p} \leq 0.05)$ in taro accessions: for example, Chiapaneca had a 0.70 UIT/100 g value, while no activity was observed in Campechana. Madrigal et al. (2018) found a higher activity of trypsin inhibitors (1424.58-2262.98 UIT/g).

The total phenol content varied significantly $(\mathrm{P} \leq 0.05)$ among the taro samples $(0.54-$ $5.76 \mathrm{~g}$ gallic acid/100g). These values are higher than $0.19 \mathrm{Eq} / \mathrm{g}$ gallic acid/100 $\mathrm{g}$ (Madrigal et al., 2018) and similar to $5.15 \mathrm{Eq} / \mathrm{g}$ of gallic acid/100 g (Eleazu et al., 2016). Eleazu et al. (2016) have reported that cooked potato has a higher concentration of total phenolic compounds than raw potato, as well as a higher concentration of phenolic compounds in the tuber peel. Genotypic variation is the predominant factor that affects the tuber's phenolic contents compared to other parameters such as location and time of year (Ji et al., 2012). Keutgen et al. (2019) reported that the composition of phenolic compounds of potatoes depends on the growing site and the variety. Meanwhile, the concentration of condensed phenolics was 1.20-4.65 g Eq/g (+) catechin/100g.

The phytic acid value of the analyzed samples ranged from 0.22 to $0.40 \mathrm{~g} \mathrm{Eq} / \mathrm{g}$ sodium phytate/100 g; these values are higher than those reported by Rodríguez et al. (2011) for taro flour $(0.6 \mathrm{~g} / 100 \mathrm{~g})$. Phytic acid is a known chelator, forming protein and phytic acid mineral complexes, resulting in a decrease in the bioavailability of both proteins and minerals (Feizollahi et al., 2021). Low phytate concentration has been proven to have a beneficial effect on their activity as antioxidants and anticarcinogens and they can potentially play an important role in controlling chronic non-communicable diseases such as hypercholesterolemia and atherosclerosis (Gemede et al., 2014; Thakur et al., 2019).

The content of saponins ranged from 0.37 to $1.02 \mathrm{Eq} / \mathrm{g}$ diosgenin/100 g sample; Campechana had the highest value. These values are higher than the $0.02 \mathrm{~g} / 100 \mathrm{~g}$ values reported by Caicedo (2013). Saponins are heat-labile and water-soluble compounds, therefore it is possible that they were lost as a result of these treatments (Güçlü-Üstündağ and Mazza, 2007). As we have already mentioned, in small amounts, the so-called nonnutritional factors are compounds that can help to prevent diseases; therefore, they have been called bioactive compounds. One of its main biological activities is its antioxidant function (Vargas et al., 2019).

\section{Antioxidant Activity}

Table 4 shows that the antioxidant capacity of the ethanolic extracts of taro flour varied from 348.63 to $573.13 \mathrm{Eq} / \mathrm{mg}$ of trolox/g of flour: the Chiapaneca accession registered the lowest value (matching the phenolic compound content). The antioxidant activity is mainly the responsibility of the phenols — particularly the flavonoids - , since they confer a strong 
Table 4. Antioxidant Activity of Taro Flour from Four Accessions.

\begin{tabular}{l|c}
\multicolumn{1}{c|}{ Accession } & $\begin{array}{c}\text { Antioxidant activity } \\
\text { (mg eq of trolox / } \mathbf{g} \text { of flour) }\end{array}$ \\
\hline Campechana & $348.63 \pm 0.39^{\mathrm{b}}$ \\
\hline Chiapaneca & $294.12 \pm 8.237^{\mathrm{c}}$ \\
\hline Tabasqueña & $517.09 \pm 1.79^{\mathrm{a}}$ \\
\hline Dulce P1 & $519.20 \pm 1.04^{\mathrm{a}}$ \\
\hline Dulce P2 & $573.13 \pm 2.58^{\mathrm{a}}$ \\
\hline
\end{tabular}

*Means with the same letters in each column are statistically equal (Tukey, $\mathrm{P} \leq 0.05)$.

antioxidant activity. In this work they are mainly attributable to this type of compounds (Baião et al., 2017).

Another important function of antioxidant molecules is their impact on health. Although humans have endogenous antioxidant systems, having more oxidant molecules than antioxidant molecules cause oxidative stress (OS). An exogenous antioxidant-rich diet can help to prevent OS damage (Pisoschi and Pop, 2015, He et al., 2017). Including taro in the diet - combined with other foods such as fruits, cereals, and fabaceae - could contribute both to a varied and balanced diet and to a better health, as they reduce the risk of such situations as: premature aging, cancer, diabetes, inflammation, liver disease, cardiovascular disease, cataracts, nephrotoxicity, and neurodegenerative disorders (Neha et al., 2019).

\section{CONGLUSIONS}

In addition to moisture, starch is the main component of taro; therefore, it represents an economical and sustainable alternative to obtain raw materials of interest to the food industry. The accessions evaluated had low concentrations of non-nutritional compounds, however, they had phenolic compounds that provide them with antioxidant activity. The characterization of these accessions opens a potential alternative use that provides an added value, which is beneficial for the producer.

\section{AGKNOWLEDGMENTS}

The authors would like to thank the Consejo Nacional de Ciencia y Tecnología (CONACyT) for the resources granted to the "Generation of Technology for the Sustainable Production and Integral Use of Taro and Cassava in Tabasco and Veracruz, Mexico" project, No. 1153, Call for National Problems Projects of 2015 .

\section{REFERENGES}

AOAC (2005). Official Methods of Analysis of Association of Official Analytical Chemist International; 18th edition, AOAC International. Maryland, USA.

Antonio-Estrada, C., Bello-Pérez, L.A., Martinez-Sánchez, G.E., Montanes-Soto, J.L., Jimenez-Hernandez, J. \& Vivar-Vera, M.A. (2009). Enzymatic production of maltodextrins from taro (Colocasia esculenta) starch. CyTA - Journal of Food 7(3):233-241, https://doi.org/10.1080/19476330903091300 
Baião, D.D.S., De Freitas, G.S., Gomes, L.P., Da Silva, D., Correa, A.C.N., Pereira, P.R., \& Paschoalin, V.M.F. (2017). Polyphenols from root, tubercles and grains cropped in Brazil: Chemical and nutritional characterization and their effects on human health and diseases. Nutrients, 9(9):1044

Barrera, V., Tapia C., \& Monteros, A. (2004). Caracterización Fisicoquímica, Nutricional y Funcional de Raíces y Tubérculos Andinos, In: Raíces y Tubérculos Andinos: Alternativas para la conservación y uso sostenible en el Ecuador. Instituto Nacional Autónomo de Investigaciones Agropecuarias, Quito, Ecuador - Lima, Perú. pp:91-116.

Caicedo, W.O. (2013). Tubérculos de papa china (Colocasia esculenta (1.) Schott) como una fuente energética tropical para alimentar cerdos, una reseña corta sobre las características de la composición química y de los factores antinutricionales. Revista Computarizada de Producción Porcina 20:278-282.

Eleazu, G. O. (2016). Characterization of the natural products in cocoyam (Colocasia esculenta) using GG-MS. Pharmaceutical Biology 54:2880-2885, https://doi.org/10.1080/13880209.2016.1190383

Ferreira, S., Ortiz, E. \& Pardo, C. (1990). Estudio químico bromatológico de la Colocasia esculenta (Taro). Revista Colombiana de Ciencias Químicas Farmacéuticas 18:53-59.

Feizollahi, E., Mirmahdi, R.S., Zoghi, A., Zijlstra, R.T., Roopesh, M.S., \& Vasanthan, T. (2021). Review of the beneficial and anti-nutritional qualities of phytic acid, and procedures for removing it from food products. Food Research International, 110284.

Gemede, H. M. (2014). Potential health benefits and adverse effects associated with phytate in foods. Food Science and Quality Management, 27, 45-55.

Güçlü-Üstündağ, Ö., \& Mazza, G. (2007). Saponins: properties, applications and processing. Critical reviewes in food science and nutrition, 47(3), 231-258.

Hiai, S., Oura, H., \& Nakajima, T. (1976). Color reaction of some sapogenins and saponins with vanillin sulfuric acid. Planta Medica 29:116-122.

He, L., He T., Farrar S., Ji L., Liu, T, \& Ma, X. (2017). Antioxidants Maintain Cellular Redox Homeostasis by Elimination of Reactive Oxygen Species. Cellular Physiology and Biochemistry 44(2):532-553. doi: 10.1159/000485089. Epub 2017 Nov 17. PMID: 29145191.

Ji, X., Rivers, L., Zielinski, Z., Xu, M., MacDougall, E., Stephen J., \& Zhang J. (2012). Quantitative analysis of phenolic components and glycoalkaloids from 20 potato clones and in vitro evaluation of antioxidant, cholesterol uptake, and neuroprotective activities. Food Chemistry 133:1177-1187, https:// doi.org/10.1016/j.foodchem.2011.08.065

Keutgen, A. J., Wszelaczyńska, E., Pobereżny, J., Przewodowska, A., Przewodowski, W., Milczarek, D., Tatarowska, B., Flis, B., \& Keutgen, N. (2019). Antioxidant properties of potato tubers (Solanum tuberosum L.) as a consequence of genetic potential and growing conditions. PloS one, 14(9), e0222976. https://doi.org/10.1371/journal.pone.0222976

Kuskoski, E.M., Asueroro, A. G., Troncoso, A. M., Garcia-Parilla, M.C., \& Fett R. (2004). Actividad antioxidante de pigmentos antociánicos. Revista Brasileira Ciencia y Tecnología de Alimentos 24:691-693.

Liu, K., \& Markakis, P. (1989). Trypsin inhibition assay as related to limited hydrolysis of inhibitors. Analytical Biochemistry 178:159-165. https://doi.org/10.1016/0003-2697(89)90373-4

Madrigal Ambriz, L. V., Hernández Madrigal, J. V., Carranco Jáuregui, M. E., Calvo Carrillo, M. de la C., \& Casas Rosado, R. de G. (2018). Caracterización física y nutricional de harina del tubérculo de "Malanga" Colocasia esculenta L. Schott) de Actopan, Veracruz, México. Archivo Latinoamerocano de Nutrición, 68:175-183. https://www.alanrevista.org/ediciones/2018/2/art-8/

Neha, K., Haider, M.R., Pathak, A., \& Yar MS. (2019). Medicinal prospects of antioxidants: A review. European Journal of Medicinal Chemistry. 15(178):687-704. doi: 10.1016/j.ejmech.2019.06.010. Epub 2019 Jun 13. PMID: 31228811.

NMX-F-277-1991: Industria Azucarera - Muestras de Jugos de Caña De Azúcar - Substancias Reductoras Método de Prueba.

Onwueme, I. (1999). Taro cultivation in Asia and the Pacific. Food and Agriculture Organization of the United Nations, Regional Office for Asia and the Pacific. Bangkok.

Pisoschi, A.M., \& Pop, A. (2015). The role of antioxidants in the chemistry of oxidative stress: A review. European Journal of Medicinal Chemistry 5(97):55-74. doi: 10.1016/j.ejmech.2015.04.040. Epub 2015 Apr 22. PMID: 25942353.

Púa-Amparo, L., Barreto-Genisberto, E., Zuleta, J.L., \& Herrera, D.O. (2019). Nutrient analysis of taro root (Colocasia esculenta Schott) in the dry tropics of Colombia. Información tecnológica 30: 69-76, https://doi. org/10.4067/S0718-07642019000400069

Rodríguez-Miranda,J., Rivadeneyra-Rodríguez, J.M., Ramírez-Rivera, E.J., Juárez-Barrientos, J.M., HerreraTorres, E., Navarro-Cortéz, R.O., \& Hernández-Santos, B. (2011). Caracterización fisicoquímica, 
funcional y contenido fenólico de harina de malanga (Colocasia esculenta) cultivada en la región de Tuxtepec, Oaxaca, México. Ciencia y Mar 43:37-47.

Subramanian, N.K., White, P.J., Broadley, M.R., \& Ramsay, G. (2011). The three-dimensional distribution of minerals in potato tubers. Annals of botany, 107(4):681-691. https://doi.org/10.1093/aob/mcr009

Temesgen, M. (2015). Nutritional potential, health and food security benfits of taro Colocasia esculenta (L.): a review. Food Science and Quality Management 36:23-30.

Thakur, A., Sharma, V., \& Thakur, A. (2019). An overview of anti-nutritional factors in food. International Journal of Chemical Studies 7(1): 2472-2479

Torres, A.L., Montero-Castillo, P.M., \& Durán, M. (2013). Propiedades fisicoquímicas, morfológicas y funcionales del almidón de malanga (Colocasia esculenta). Revista Lasallista de Investigación 10:52-61.

USDA (2013). United States Department of Agriculture. Database for the Flavonoid Content of Selected Foods. Available online: https://www.ars.usda.gov/ARSUserFiles/80400525/Data/Flav/Flav3-1.pdf.

Vaintraub, I.A., \& Lapteva, N.A. (1988). Colorimetric determination of phytate in unpurified extracts of seeds and the products of their processing. Analytical Biochemistry 175:227-230.

Vargas V.M.L., Figueroa-Brito, H., Tamayo-Cortez, J.A., Toledo López V. M., \& Moo-Huchin V.M., (2019). Aprovechamiento de cáscaras de frutas: análisis nutricional y compuestos bioactivos. Ciencia ergo-sum 26:1-12, https://doi.org/10.30878/ces.v26n2a6

Viloria, H., \& Córdova, C. (2008). Sistema de producción de ocumo chino (Colocasia esculenta (L.) Schott) en la Parroquia Manuel Renaud del Municipio Antonio Díaz del Estado Delta Amacuro, Venezuela. Revista UDO Agrícola 8:98-106. 